UDC $902.01 / 903$

Submitted: 17.02 .2020

LBC 63.4

Accepted: 29.04 .2020

\title{
TO THE QUESTION OF THE SO CALLED SAUROMATIC MIRROR FROM THE OGUZ KURGAN
}

\author{
Tatiana M. Kuznetsova
}

Institute of Archaeology of the Russian Academy of Sciences, Moscow, Russian Federation

\begin{abstract}
The article continues the discussion about the object, which was discovered in the Oguz kurgan and is referred to as the sauromatian "mirror" in the literature. A round disk (with a flat side handle) shows a corrugation on its two sides. The purpose of such a thing that does not have a reflective surface is difficult to determine. However, it cannot be called a "mirror" because of the corrugation, so the function of the object has not yet been determined. This item was located under the back of a woman buried in the northern niche of the kurgan. Having identified an object from the Oguz barrow as a mirror, its researchers established the role of mirrors in the funeral rite of the Black Sea Scythia. They put forward the postulate that the mirrors among the accompanying equipment, laid under the back or left forearm of the deceased, fixate funerary complexes of dependent women of Scythia in the $5^{\text {th }}-4^{\text {th }}$ centuries BC. However, there is no pattern detected in the placement of mirrors alongside with buried ones in the North Pontic region. This does not allow us to present a real picture of the role of mirrors in the funeral rite of the Scythians or their neighbors and to clarify the social status of those buried by the location of these objects. The same picture is revealed when analyzing the placement of mirrors in the graves of sauromates. Studies of the funeral rite show that nomads were united only by desire of the mirrors' owners to protect their mirror surface from damage that could distort the image of the owner. Therefore, it seems not advisable to equate objects with corrugation on both sides of their disks with mirrors, without taking the differences into account.
\end{abstract}

Key words: mirrors, corrugation, Oguz kurgan, rite, Scythians, Sauromats, Sarmatians.

Citation. Kuznetsova T.M., 2020. To the Question of the So Called Sauromatic Mirror from the Oguz Kurgan. The Lower Volga Archaeological Bulletin, vol. 19, no. 1, pp. 46-63. (in Russian). DOI: https://doi.org/10.15688/ nav.jvolsu.2020.1.3

УДК $902.01 / 903$

Дата поступления статьи: 17.02.2020

ББК 63.4

Дата принятия статьи: 29.04.2020

\section{К ВОПРОСУ О ТАК НАЗЫВАЕМОМ САВРОМАТСКОМ ЗЕРКАЛЕ ИЗ КУРГАНА «ОГУЗ»}

\author{
Татьяна Михайловна Кузнецова \\ Институт археологии РАН, г. Москва, Российская Федерация
}

\begin{abstract}
Аннотация. В статье продолжена дискуссия о предмете, который был найден в кургане «Огуз» и в литературе именуется савроматским «зеркалом». У круглого диска (с плоской боковой ручкой) прослежено рифление на двух его сторонах. Назначение такой вещи, не имеющей отражающей поверхности, определить сложно. Однако и «зеркалом» из-за рифления назвать нельзя, поэтому функция предмета пока не определена. Этот предмет располагался под спиной женщины, погребенной в северной нише кургана. Обусловив предмет из кургана «Огуз» как зеркало, его исследователи установили роль зеркал в погребальном обряде Причерноморской Скифии. Ими был выдвинут постулат о том, что зеркала в составе сопровождающего инвентаря, положенные под спиной или левым предплечьем усопшей, фиксируют в V-IV вв. до н.э. погребальные комплексы зависимых женщин Скифии. Однако в расположении зеркал при погребенных для Северопричерноморского региона закономерности не прослеживаются. Это не позволяет представить реальную картину роли зеркал в погребальном обряде скифов или их соседей и уточнить по расположению этих (2) предметов социальный статус погребенных. Такая же картина выявляется и при анализе размещения зеркал
\end{abstract}


в могилах савроматов. Исследования погребального обряда показывают, что кочевников объединяло лишь желание обладателей зеркал предохранить их зеркальную поверхность от повреждения, которое могло исказить образ владельца. Оттого предметы, имеющие двухстороннее рифление на диске, уравнивать с зеркалами, не учитывая различий, представляется нецелесообразным.

Ключевые слова: зеркала, рифление, курган «Огуз», обряд, скифы, савроматы, сарматы.

Цитирование. Кузнецова Т. М., 2020. К вопросу о так называемом савроматском зеркале из кургана «Огуз» // Нижневолжский археологический вестник. Т. 19, № 1. С. 46-63. DOI: https://doi.org/10.15688/ nav.jvolsu.2020.1.3

\section{Вступление}

Предмет, который был найден в кургане «Огуз» (рис. 1,1$)^{1}$, в литературе всегда именовался «зеркалом», и мне пришлось к нему обратиться при сборе материала еще в 1984 году. Позднее хранитель этой вещи А.Ю. Алексеев, который писал о нем как о «позднесавроматском» зеркале [Алексеев, 1987 , с. 46$]$, любезно разрешил мне опубликовать еще никем не изданный материал [Кузнецова, 2001a, с. 140 , рис. $5, A ; 2002$, с. 123 , № 387; 2010, с. 270, табл. 161/А].

В результате была представлена реконструкция огузского экземпляра (рис. 2,1) и написана специальная статья для того, чтобы обратить внимание исследователей на форму вещи, которая была встречена в единственном экземпляре на территории Скифии, однако являлась характерной для памятников, связываемых с савроматами, где все похожие предметы были отнесены к категории «зеркала». Однако в кургане «Огуз» был обнаружен экземпляр, имевший круглый диск с двухсторонним рифлением и плоскую боковую ручку [Кузнецова, 2001a, с. 140, рис. $5,5-\Gamma]$, который с «зеркалом» связать было нельзя.

Специалисты установили, что зеркала в области распространения савроматской культуры производились по единой технологической схеме, связанной с горячей ковкой высокооловянистых бронз, характерной для стран Востока, где таким же образом изготавливалась и посуда [Равич, 2006, с. 48-49]. Относительно огузского экземпляра И.Г. Равич высказала мнение, что «зеркало изготовлено из двойной высокооловянистой бронзы, содержащей 25 \% олова», а рифление на поверхности диска с двух сторон, отмеченное мной ранее, является вмятинами, связанными с горячей ковкой [Равич, 2006, с. 47].
Однако находка на Среднем Дону в кургане 18 (погребение 1) могильника Колбино I, соотносимого со скифами [Гуляев, Савченко, 1999, с. 151-157, рис. 2,11], изготовленная по той же технологии [Равич, 2006, с. 47-48], имеет и рифление на одной стороне, и сохранившуюся полировку на другой - гладкой стороне диска (рис. 2,2), свидетельствующую о том, что подобными предметами могли быть и зеркала. К зеркалам была отнесена и находка из погребения 1 кургана 8 Песочинского курганного могильника на Северском Донце (рис. 2,3), имевшая ровную рабочую сторону со следами хорошей полировки [Бабенко, 2005, с. 119 , рис. 18,5 ; с. 149; Кузнецова, 2010 , с. 262 , рис. 54, № 441-а]. Поэтому говорить о деформации огузского предмета, связанной с технологией его изготовления, отмеченной И.Г. Равич, нет основания.

Таким образом, вещи близкой формы распределились по двум группам: зеркала и похожие на них объекты.

Термином «зеркало» в научной литературе определяется тщательно отполированная поверхность, воспроизводящая изображения объектов, расположенных перед ней, по законам отражения [Научно-технический энциклопедический словарь, 2001], то есть стеклянное или металлическое тело с отражающей поверхностью, которая отполирована так, что ее неровности не превышают долей длины электромагнитной или звуковой волны [Современный толковый словарь, 1998].

Поскольку предмет из кургана «Огуз» имел рифленую поверхность диска с двух сторон, нарушавшую и искажавшую отражение, он не мог служить зеркалом. Достоверно и сейчас пока можно указать аналогичное рифление только на находке из Оренбургской области, обнаруженной в кургане 3 (погребение 1) могильника у с. Гумарово (рис. 2,4), ко- 
торая также не была зеркалом [Зуев, Исмагилов, 1999, с. 117, табл. 7,1].

Тем не менее даже наличие всего двух предметов, которые не имели отражающей поверхности, позволило предполагать и отличие их функции в сравнении с зеркалами.

Разделение и подробный анализ указанных форм для савроматского материала, как уже говорилось, нуждаются в дополнительной работе, поэтому пришлось обратить внимание на существенное расхождение между формой некоторых и приписываемой им функцией.

Зеркала в первую очередь предназначались и использовались для смотрения в них. Об этом свидетельствует и этимология терминов, обозначающих «зеркало» у различных народов. В иранских и таджикских языках оно восходит к древнеиранскому «глядеть» [Аба-

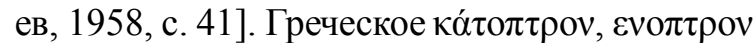

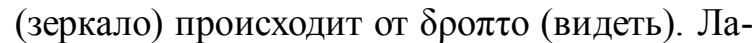
тинское speculum, итальянское specchio, немецкое Spiegel идет от spectare (смотреть). Французское miroir и английское mirror - от латинского mirari - смотреть, восхищаться, удивляться [Молок, 2015, с. 93]. То же мы видим и в словенском - ź́kalo «зрачок», zrkálo, zrcálo «зеркало», чешском - zrcadlo, zrkadlo, словацком - zrkadlo, полабском - zarḱódlü «зеркало» (и сюда же зе́ркать, «шнырять глазами»), в украинском - зе́ркало и церковном зерца́ло - языках [Фасмер, 1986, с. 95].

По этнографическим данным исследователи констатировали представления о зеркалах у различных народов, которые верят, что отражение в зеркале или воде содержит душу человека. Андаманцы считают душами отражение в любом зеркале. В Новой Каледонии старики верят, что отражение человека в воде или в зеркале является его душой, а люди помоложе, обученные католическими священниками, утверждают, что отражение является не более как отражением, вроде отражения пальмы в воде. Душа-отражение, будучи внешней по отношению к человеку, подвержена многим опасностям [Фрезер, 1980, с. 219 220]. Туземцы острова Фиджи различают «темную душу» человека, или тень, которая идет в Аид, и его «светлую душу», или отражение в воде и зеркале, которое остается там, где он умирает [Тайлор, 1989, с. 216]. Душа человека, таким образом, представляется воплощенной в тени или отражении, что делает их источниками опасности. Ведь если им наносится ущерб, то это отражается и на личности владельца [Фрезер, 1980, с. 217-218].

Очень интересным и важным в этой связи является объяснение повреждения отражающей стороны зеркала, то есть суеверия, до сего времени бытующего среди русского населения, где разбившееся зеркало влечет за собой смерть владельца. У иранцев существует предсказание по поводу зеркала, присутствовавшего на свадьбе: если разобьется «зеркало счастья невесты, то невеста или жених умрет» [Хедаят Садек, 1958, с. 285]. Б.А. Литвинский отмечал наличие подобного суеверия и у таджиков [Литвинский, 1978, c. 106]. У осетин до наших дней бытует примета, что разбитое зеркало сулит несчастье [Кусаева, 2016, с. 65].

Все зафиксированные для различных народов предсказания имеют одну общую черту: вред, причиненный отражению, связанный с искажением образа, влечет за собой гибель владельца, - и демонстрируют страх живых перед последствиями, связанными с повреждением относящихся к ним вещи и/или образа.

Поскольку функцию рифленого с двух сторон предмета (круглый диск с плоской боковой ручкой) из кургана «Огуз» определить было сложно, а «зеркалом», исходя из сказанного выше, назвать нельзя, пришлось предположить, что, по всей вероятности, он мог быть использован как культовая «жаровня» или «курильница», а возможно, как-то иначе. Мне, наверное, следовало бы продолжить список определений для предметов, называемых зеркалами и имевших даже и две гладкие стороны, так как их атрибуция не всегда является безусловной для ученых, которые предполагали, что они могли быть или «крышками», или «опахалами» [Woolley, 1934a, p. 310; 1934b, pl. 230; Albenda, 1985, p. 2; Schmidt, 1937, p. 422, 456, pl. LIV].

Однако главная задача состояла в том, чтобы показать следующее: огузский экземпляр зеркалом служить не мог и был предназначен для каких-то иных целей, возможно жреческих, что требовало большой работы с савромато-сарматскими находками, которую могли бы проделать специалисты, разрабаты- 
вающие материалы, связанные с кругом этих культур. Говоря о савроматском материале, я действительно не исключала, что такие предметы, а не зеркала, о чем писали и пишут исследователи [Смирнов, 1964, с. 249; Королькова, 1997, с. 32], могли входить в состав «жреческого комплекса» савроматской культуры. Однако для выяснения этого предлагалось провести подсчеты по каждому из савроматских могильников, в которых они были найдены, выделить отличительные черты в сочетании с сопроводительным инвентарем, определить их численность в каждом конкретном месте и в определенное время [Кузнецова, 2001б], что, скорее всего, опровергло бы идею о жреческих комплексах, входивших в состав одновременных могильников.

Результат высказанных пожеланий проявился в среде скифологов, но с точностью до наоборот. Уважаемые мной коллеги сделали вывод, который никоим образом не вытекает из моих текстов, посчитав, что я атрибутирую огузский экземпляр как культовую «жаровню» или «курильницу» [Бабенко, 2005, с. 149; Болтрик, Фиалко, 2011, с. 93]. В этом, конечно, есть и моя вина, так как не стоило делать подобных догадок, даже с оговорками, а сказать, что функция предмета не определяется.

\section{Не жрецы и не шаманы}

Ю.В. Болтрик и Е.Е. Фиалко, выявив, что зеркало из «Огуза» действительно имело «с одной стороны в центре плоского диска незначительное округлое вдавление», а «с обратной стороны - на гладком диске едва заметное рельефное выступание», которое не могло не исказить образ смотрящегося, высказали мнение, что «относительно зеркал (назовем их условно огузского типа) с округлым углублением в центре (рис. 1,2) Т.М. Кузнецова решительно высказывается в пользу их определения как однозначно культовых предметов (а не зеркал как таковых), входивших в состав “жреческого комплекса”. На ее взгляд, подобные предметы могут оказаться очень важным аргументом и в решении вопроса о принадлежности лиц, погребенных в сопровождении “жертвенников”... если рассматривать их не только в рамках археологической куль- туры, а в рамках каждого могильника, учитывая, что жрец (колдун, шаман и т. п.) - явление уникальное в социуме... [Кузнецова, 2001a, с. 133-134]. Соглашаясь в целом с мнением исследовательницы, позволим себе все же выделить огузский экземпляр из собственно шаманских комплексов. Наличие этого зеркала в составе более чем скромного сопроводительного набора... безусловно, соотносится с захоронением служанки. При этом характер деталей набора определяет его как бесспорно женский» [Болтрик, Фиалко, 2011, c. 93-94].

Однако из приведенной цитаты никоим образом не следует, что я вижу в огузском экземпляре элемент, составляющий жреческо-шаманский комплекс в скифском социуме. Из-за смещения акцента в этом случае мое категоричное высказывание относительно незеркальной принадлежности предмета из «Огуза», озвученное исследователями [Болтрик, Фиалко, 2011, с. 93, 94], приняло ошибочную форму, так как не соответствовало и не соответствует моей точке зрения [Кузнецова, 2001a, с. 133-134; 2001б].

Более того, о вопросе, связанном с наличием «жреческого сословия» у скифов, мне приходилось писать и прежде, где отмечалось, что он остается достаточно спорным, так как в письменных источниках отсутствуют сведения об участии специальных лиц (жрецов), совершавших обряд или руководивших им. Исходя из этого, наиболее вероятным представляется, что жреческое сословие у скифов отсутствовало [Кузнецова, 2008, с. 173]. Я разделяю точку зрения С.С. Бессоновой о том, что «жреческие функции» могли входить в сферу деятельности главы социума [Бессонова, 1983, с. 59].

Помимо этого, ранее, связывая «Бердянский» курган с захоронением Орика, одного из сыновей скифского царя Ариапифа, мне приходилось говорить о том, что «жрица» не могла быть погребена в Восточной (одновременной с центральной) могиле этого кургана [Кузнецова, 2001 в, с. 146-149], вопреки мнению его исследователей [Чередниченко, Фиалко, 1988; Болтрик и др., 1994, с. 153].

При этом еще раз следует подчеркнуть, что служителей культов не хоронили и не хоронят в общих усыпальницах, даже в рамках 
могильника (кладбища). В этнографической литературе не удалось найти фактов, доказывающих возможность захоронения людей, отправлявших культовые церемонии, на одном сакральном пространстве с остальными представителями социума, и тем более в «сопутствующих» усыпальницах, тогда как примеры изоляции таких могил отмечены для населения, имевшего различное вероисповедание [Дьяконова, 1975, с. 77, 116; Кенин-Лопсан, 1987 , с. $84 ; 2009$, с. 116$]$.

Мнение Ю.В. Болтрика о том, что в Восточной могиле Бердянского кургана были захоронены «зависимые лица», вполне справедливо [Болтрик, 2001], однако уже было отмечено ранее, что жрица не могла быть «зависимым» от главы социума лицом [Кузнецова, 2015, с. 93-94]. В настоящее время выяснилось, что я была права, и нежреческая атрибуция покойной в Восточной могиле «Бердянского» кургана Ю.В. Болтриком уже не оспаривается, поскольку это выявилось в результате внимательного исследования памятника [Болтрик, 2016, с. 29-30; 2018, с. 315316]. Однако уважаемый Юрий Викторович мое мнение на этот счет по странной случайности упустил.

\section{Зеркала и похожие на них предметы в захоронениях}

Необходимо напомнить, что в кургане «Огуз» так называемое зеркало поместили под спиной служанки, и «ручка его была развернута наружу, перпендикулярно ее телу» [Болтрик, Фиалко, 2011, с. 86]. В могильнике у с. Гумарово (кург. 3) предмет, аналогичный огузскому экземпляру, находился в женской (?) могиле, в западной части ямы, видимо слева, у головы погребенной [Зуев, Исмагилов, 1999, с. 108,118 , табл. 6].

Определив огузский экземпляр как зеркало, исследователи установили роль этих вещей в погребальном обряде Причерноморской Скифии, отобрав тот материал, который более всего подтверждал, по их мнению, идею о том, что в «Огузе», возможно, захоронена «служанка», которую исследователи отнесли к зависимой категории лиц - «ферапонтам». Однако зависимый характер погребенной соответствует ее местоположению в кургане и не вызывает возражений, как и возможное савроматское происхождение предмета, связанного со «служанкой» из «Огуза» [Болтрик, Фиалко, 2011, с. 92-93].

Вызывают возражение обобщающие выводы о том, что «зеркала в составе сопровождающего инвентаря, положенные под спиной или левым предплечьем усопшей», фиксируются в погребальных комплексах зависимых женщин Скифии V-IV вв. до н.э., «сопровождавших своего патрона в загробный мир», и что эти «комплексы являются погребениями соумирающих», то есть все синхронны основным захоронениям. Таким выводам противоречат и данные подборки, представленной исследователями для подтверждения выдвинутой ими идеи (Акимовка, кург. 11, погр. 2; Капуловка II, кург. 1, погр. 1; группа БОФ, кург. 13, погр. 2; Богдановка, кург. 1, погр. 2; III Испанова Могила, погр. 2; Верхнетарасовка, кург. 49, погр. 2; Носаки, кург. 12, м. 2, погр. 1).

Нет основания сомневаться в том, что у Ю.В. Болтрика и Е.Е. Фиалко имеется собственный научный взгляд на интерпретацию последовательности захоронений в указанных памятниках, поскольку они пишут, что «анализ местоположения этих могил в кургане и случаи уверенной фиксации подобных захоронений как синхронных основным убеждают, что эти комплексы являются погребениями соумирающих», но они этот анализ, к сожалению, не приводят, а ссылаются на данные авторов раскопок, где материал представлен иначе.

Следует отметить, что в Акимовке (кург. 11, погр. 2) зеркало находилось у предплечья левой руки погребенной и было поставлено на ребро [Болтрик, Фиалко, 2010, с. 110, рис. 7], а в погребении 1 этого же кургана, в котором все захоронения считают единовременно совершенными, зеркало лежало при парном захоронении в ногах покойной [Болтрик, Фиалко, 2010, с. 105, рис. 2], в Капуловке II (кург. 1, погр. 1) и в группеБОФ (кург. 13, погр. 2) зеркала хотя и лежали под левым плечом погребенных, но находились во впускных могилах, что не указывает на их синхронность с основными погребениями [Тереножкин и др., 1973 , с. 127 , рис. 13 ; с. 162 , рис. 44]. В Богдановке (кург. 1, погр. 2) зеркало найдено во впускной могиле и лежало слева у головы по- 
койного [Битковский, Полин, 1987, с. 74, 79, рис. 1], в III Испановой Могиле, во впускном погребении 2, девочка-подросток лежала на правом боку, а зеркало располагалось справа у ее головы [Мозолевский, 1980, с. 142-143, рис. 75], в могильнике у с. Верхнетарасовка (кург. 49, погр. 2) зеркало обнаружено во впускном захоронении, где были погребены женщина и ребенок, и находилось у левого плеча женщины, а в основной могиле этого кургана были захоронены два взрослых человека [Бунятян и др., 1977, с. 104-108]. У с. Носаки (кург. 12, м. 2, погр. 1) зеркало найдено в центральной гробнице, его расположение по отношению к погребенному - не ясно [Бидзиля и др., 1977, с. 142-143].

К этому следует добавить, что в скифском Светловодском грунтовом могильнике (более 150 захоронений) зеркала найдены в 8 могилах, датирующихся IV в. до н.э. Достоверно определяется, что они находились или под левым плечом (3 случая), или на нем (1 случай), или у головы (?) (1 случай) погребенных, принадлежавших к «зажиточной части общины» [Могилов, 2017, с. 93; 2019] и никого не сопровождавших.

В курганном могильнике Мамай-Гора для конца V-IV вв. до н.э. (370 скифских погребальных комплексов) зеркала, где это можно определить (9 из 11 экз.), располагались или за черепом (3 случая), или справа от покойных (3 случая), или под правым плечом (1 случай), или справа на теле погребенных (2 случая) даже в парных могилах [Андрух, Тощев, 1999, с. 180-184; Андрух, 2001, с. 240-245; Андрух, Тощев, 2004, с. 138-140; 2012, с. 489; 2018, c. 232-240].

Песочинский могильник (середина - вторая половина V - конец IV в. до н.э.) имеет неоднозначное этническое определение. Автор раскопок В.Г. Бородулин видел в курганах этого могильника захоронения «собственно скифов» [Бабенко, 2005, с. 186]. Исследователь некрополя Л.И. Бабенко предлагает рассматривать захоронения в нем как «оставленные либо представителями... миграционной волны, вытесненными степными кочевниками из некоторых лесостепных районов и продвинувшимися в северскодонецкий регион во второй половине V в. до н.э., либо потомками (второе-третье и последующие по- коления) таких же мигрантов, пришедших сюда еще в начале $\mathrm{V}$ в. до н.э. и довольно быстро занявших одну из ведущих позиций в общественной жизни местных племен» [Бабенко, 2005 , с. 208]. С.Ю. Гуцалов полагает, что население, оставившее могильник у с. Песочин, появилось в результате миграции достаточно большого массива племен центрально-азиатского происхождения [Гуцалов, 2009, с. 75-77].

В Песочинском могильнике из 5 зеркал, обнаруженных в 37 погребальных комплексах, достоверное расположение зеркала относительно погребенного прослежено в двух могилах. В кургане 8 (погр. 1) оно находилось справа на уровне груди одной из женщин (3 погребенных), а в кургане 18 (погр. 1), где были захоронены (единовременно с погребенными в погр. 2) мужчина и женщина, зеркало лежало между бедренными костями женщины [Бабенко, 2005, с. 19-20, 25, рис. 14].

Однако категоричное утверждение о том, что тезис о размещении «зеркала под телом свидетельствует о зависимом статусе погребенной женщины, является полностью надуманным» [Полин, Дараган, 2019, с. 212], выглядит недостаточно корректно, поскольку здесь можно говорить лишь об отсутствии необходимого доказательства. В данном случае не решают вопрос сведения и о том, что высказанное Ю.В. Болтриком и Е.Е. Фиалко предположение «абсолютно опровергается находкой зеркала под левой лопаткой “царицы” в боковой гробнице Толстой Могилы» [Полин, Дараган, 2019, с. 212], так как была ли дама, погребенная в этом кургане царицей, тоже нужно доказывать.

Таким образом, в расположении зеркал для захоронений Северопричерноморского региона не прослеживается единообразия, и это не дает пока возможности представить реальную картину роли зеркал в погребальном обряде скифов или их соседей и уточнить по расположению этих предметов социальный статус погребенных. Разграбленность захоронений еще более осложняет трактовку зеркал в погребальной обрядовой практике.

Приведенный материал всех рассмотренных памятников показывает, что обобщение по поводу того, что зеркала, положенные под спиной или левым предплечьем погребенной, фиксируют захоронения зависимых жен- 
щин Скифии V-IV вв. до н.э., сделано преждевременно и, к сожалению, без достаточного основания.

По этой причине вопрос о роли зеркал в скифских захоронениях пока остается открытым, поскольку и новые исследования, проведенные С.В. Полиным и М.Н. Дараган, к положительному результату не привели [Полин, Дараган, 2019].

Однако, учитывая предположениеЮ.В. Болтрика и Е.Е. Фиалко о савроматском происхождении «служанки» из Огуза, следовало бы обратить внимание и на расположение зеркал в могилах носителей этой культуры. Правда, определение «служанки» в качестве «ферапонта» противоречит идее об ее принадлежности по рождению к савроматам [Болтрик, Фиалко, 2011, с. 93], так как, судя по употреблению этого статусного определения «у Геродота и в близких по времени источниках, это придворные чины, причем единоплеменники царя, свободные или благородные» [Грантовский, 1980, с. 131].

Следствием работы Ю.В. Болтрика и Е.Е. Фиалко стал «этюд», предложенный В.И. Гуляевым, где он с удивлением отметил, что «точных параллелей среди многочисленных бронзовых зеркал с боковыми ручками V-IV вв. до н.э. с территории Скифии» не нашел, что уже и ранее отмечалось, а обнаружил ближайшие аналогии колбинскому зеркалу на Южном Урале (рис. 2,5), в кургане 3 (погр. 1) могильника у с. Филипповка [Гуляев, 2018, c. 573].

Вот здесь бы и посмотреть на место зеркал в могилах Филипповки и сопоставить с имеющимися данными по Северному Причерноморью, но автор сравнил лишь описания погребений и никакого вывода не сделал вообще, присоединившись к мнению исследователей о магической роли зеркал у кочевников и к заключению о том, что срок их эксплуатации не превышал по времени одно поколение, поскольку служили зеркала только своим непосредственным хозяевам и не передавались по наследству [Гуляев, 2018, с. 572-574].

В Филипповском могильнике V-IV вв. до н.э. (29 курганов) обнаружено 18 зеркал в 11 погребениях. Расположение всех зеркал в его могилах так же, как и для Скифии, очень разнообразно (см. табл. 1) и не позволяет пока выявить какую-то закономерность в действиях савроматов по отношению к погребаемым и их зеркалам [Пшеничнюк, 2012; Яблонский, 2013;2015].

Местоположение зеркал, похожих на огузский предмет, также не имеет между собой сходства при их захоронении в могильнике у с. Филипповка. Одно из зеркал (кург. 3, погр. 1) обнаружено в основной могиле, где было захоронено двое мужчин и женщина. Зеркало (рис. 2,5) располагалось рядом с левой ступней одного из мужчин (?) [Пшеничнюк, 2012, с. 34-36, рис. 63, 65]. В кургане 7 были обнаружены 6 человеческих захоронений в одной могиле. Рядом с двумя из покойных найдены зеркала. Одно находилось справа у черепа костяка 3 (рис. 3,1 ), одно у черепа справа от костяка 5 (рис. 3,2-3), а третье лежало на его же груди [Пшеничнюк, 2012, с. 4344, рис. 91, 94-95]. В кургане 11 (погр. 1), где было захоронено трое человек (М, Ж, ?), зеркало лежало у левого локтя женщины (рис. 3,4) под колчаном со стрелами [Яблонский, 2013, с. 131, № 1496], а в кургане 15 (погр. 1) зеркало (рис. 2,6) находилось между скелетами 2, 3 и 1, 4. В этом же кургане (погр. 2) зеркало находилось у правого плеча погребенной (рис. $3,5)$, а в погребении 4 - у восточной стенки (рис. 3,6), рядом с деревянными чашами [Яблонский, 2013, с. 131, № 1496; 2013, с. 148149, 159, № 1836, 1840, 1969]. В кургане 24 (погр. 1) расположение зеркала по отношению к погребенному не ясно [Пшеничнюк, 2012, с. 60 , рис. 149$]$.

Нет единства в расположении подобных зеркал и в Северопричерноморских памятниках. В Песочинском могильнике на Северском Донце, обнаружены трое «соумирающих» (кург. 8, погр. 1), из которых - две женщины. Зеркало лежало справа от одной из женщин на уровне ее груди [Бабенко, 2005, с. 20, рис. 14]. В могильнике Колбино I (кург. 18, погр. 1), где во впускной гробнице было обнаружено двое покойных: женщина лет 55-60 и мужчина 35-40 лет (мужчину положили несколько позже), - зеркало лежало в ногах погребенной [Гуляев, 2000, с. 39, 43].

Не выявилось системы в местоположении зеркал и в более позднее время. В погребениях, относящихся к нижнедонским раннесарматским памятникам II-I вв. до н.э., где 
Таблица 1. Расположение зеркал в погребениях могильника у с. Филипповка

Table 1. Location of mirrors in the graves of the burial ground near Filippovka village

\begin{tabular}{|c|c|c|c|c|c|c|c|c|}
\hline \multicolumn{9}{|c|}{ Зеркала в могильнике у с. Филипповка } \\
\hline $\begin{array}{l}\text { № } \\
\text { ח/ח }\end{array}$ & $\begin{array}{c}\text { № } \\
\text { кур- } \\
\text { гана }\end{array}$ & $\begin{array}{l}\text { № по- } \\
\text { гребе- } \\
\text { ния }\end{array}$ & $\begin{array}{c}\text { Сохран- } \\
\text { ность } \\
\text { погребе- } \\
\text { ния }\end{array}$ & $\begin{array}{c}\text { Количе- } \\
\text { ство по- } \\
\text { гребен- } \\
\text { ных }\end{array}$ & $\begin{array}{l}\text { Пол по- } \\
\text { гребен- } \\
\text { ного }\end{array}$ & $\begin{array}{l}\text { Коли- } \\
\text { чество } \\
\text { зеркал }\end{array}$ & $\begin{array}{c}\text { Сохран- } \\
\text { ность } \\
\text { зеркала }\end{array}$ & $\begin{array}{c}\text { Расположение в могиле } \\
\text { по отношению } \\
\text { к погребенному }\end{array}$ \\
\hline 1 & 1 & 2 & + & 1 & Ж & 1 & + & у головы \\
\hline 2 & 3 & 1 & + & 3 & Ж, M, M & 1 & + & $\begin{array}{c}\text { рядом с левой ступней } \\
\text { одного из М }\end{array}$ \\
\hline 3 & 4 & 4 & + & 2 & M, Ж & 1 & + & на блюде № 2 \\
\hline 4 & \multirow{3}{*}{7} & \multirow{3}{*}{1} & \multirow{3}{*}{$0 /+$} & \multirow{3}{*}{6} & костяк 3 & 1 & + & справа у черепа \\
\hline 5 & & & & & \multirow{2}{*}{ костяк 5} & 1 & + & справа от черепа \\
\hline 6 & & & & & & 1 & + & на груди \\
\hline 7 & 11 & 1 & $0 /+$ & 3 & M, Ж,? & 1 & + & $\begin{array}{c}\text { у левого локтя Ж, } \\
\text { под колчаном со стрелами }\end{array}$ \\
\hline 8 & \multirow{2}{*}{14} & 1 & + & 1 & Ж & 1 & + & справа у черепа \\
\hline 9 & & 2 & $0 /+$ & 3 & M, Ж, ? & 1 & + & слева у черепа Ж \\
\hline 10 & \multirow{3}{*}{15} & 1 & $0 /+$ & 8 & $?$ & 1 & + & $\begin{array}{c}\text { между скелетами } \\
2,3 \text { и } 1,4 \\
\end{array}$ \\
\hline 11 & & 2 & + & 1 & Ж & 1 & + & у правого плеча \\
\hline 12 & & 4 & + & 1 & Ж & 1 & + & $\begin{array}{c}\text { у восточной стенки, рядом } \\
\text { с деревянными чашами }\end{array}$ \\
\hline 13 & \multirow[b]{2}{*}{16} & 2 & + & 1 & Ж & 1 & + & у правого предплечья \\
\hline 14 & & 3 & + & 1 & Ж & 1 & + & $\begin{array}{c}\text { внутри тлена от деревян- } \\
\text { ной чаши }\end{array}$ \\
\hline 15 & \multirow{2}{*}{24} & 1 & + & 1 & Ж & 1 & + & не ясно \\
\hline 16 & & 3 & + & 1 & Ж & 1 & + & справа от черепа \\
\hline 17 & \multirow{2}{*}{29} & 4 & + & 1 & Ж & 1 & + & в ногах погребенной \\
\hline 18 & & 6 & + & 1 & Ж & 1 & + & у левой голени \\
\hline
\end{tabular}

В.П. Глебовым учтено 125 зеркал и их фрагментов [Глебов, 2019, с. 87], существенных различий в расположении в могилах рассматриваемых предметов исследователем не отмечается, поскольку «почти все зеркала и фрагменты зеркал располагались близко к телу погребенного, нередко вплотную, иногда на теле или под ним».

Зеркала или их фрагменты зафиксированы возле черепа, плеч, груди погребенного, зачастую под костями или сверху - 51 \% (чаще справа), реже в районе колен, голеней и стоп $23 \%$, в области живота, таза и бедер - 21,2\% (чаще справа). Исследователь отмечает также, что чаще всего находки располагаются ближе к правому локтю. В стороне от тела зеркала или их фрагменты зафиксированы лишь в единичных случаях - трижды справа, дважды слева [Глебов, 2019, с. 91].

Интерпретацию по вопросу о сроке эксплуатации зеркал у скифов, который, по мнению исследователей, «не превышал по времени одно поколение, поскольку служили зерка- ла только своим непосредственным хозяевам и не передавались по наследству» [Болтрик, Фиалко, 2011, с. 92-93], можно связать с большой увлеченностью авторов возникшей идеей при написании статьи, поскольку в этом же году Е.Е. Фиалко справедливо отметила, что «зеркала - привозные, и, соответственно, дорогие предметы - высоко ценились, могли передаваться из поколения в поколение; во всяком случае, нередко в погребение они попадали сильно изношенными и поврежденными, то есть после длительного использования» [Фиалко, 2011, с. 82].

Этот вывод подтверждается и тем, что в скифских памятниках IV в. до н.э. получают распространение зеркала с замененными ручками и греческими дисками, время появления которых ограничивается серединой V в. до н.э., что демонстрирует их вторичное употребление [Кузнецова, 2010, с. 41 и сл.].

Использование населением на территории распространения савромато-сарматских памятников починенных зеркал и их отдельных фраг- 
T.M. Kuznetsova. To the Question of the So Called Sauromatic Mirror from the Oguz Kurgan

ментов также указывает, помимо всего прочего, на стремление увеличить срок функционирования этих вещей [Скрипкин, 1990, с. 90].

Хранение зеркал в специальных чехлах или футлярах из кожи, дерева и ткани [Скрипкин, 1990, с. 90; Андрух, Тощев, 1999, с. 32] связано со стремлением их владельцев защитить зеркальную поверхность, а следовательно и образ от возможных повреждений. Сведения о зеркалах показывают желание обладателей зеркала предохранить отражающую поверхность от повреждения, которое могло исказить образ его хозяина, что и выявляет фиксация зеркал в погребальном обряде.

Для вещей, которые близки по форме савроматским зеркалам, но не соответствуют их функции, оберегающие «футляры» пока не зафиксированы. Близкие савроматским зеркалам формы встречены пока по одному в памятниках разных археологических культур: курган «Огуз» (скифы) и курган 3 у с. Гумарово (савроматы). Правда, в «Огузе» предполагается захоронение одной из савроматских женщин, чьей-то дочери, проданной, согласно Плутарху, скифам во время «попойки» [Болтрик, Фиалко, 2011, с. 93]. Поэтому сравнивать их роль в обряде еще сложнее. Для этого требуются дальнейшие наблюдения. Однако и приравнивать предметы, не имевшие отражающей поверхности из-за двухстороннего рифления на диске, к зеркалам, не считаясь с их различиями, представляется нерациональным.

\section{ПРИМЕЧАНИЕ}

${ }^{1}$ Хранится в Отделе археологии Восточной Европы и Сибири Государственного Эрмитажа, инв. № Дн 1894 1/62. 


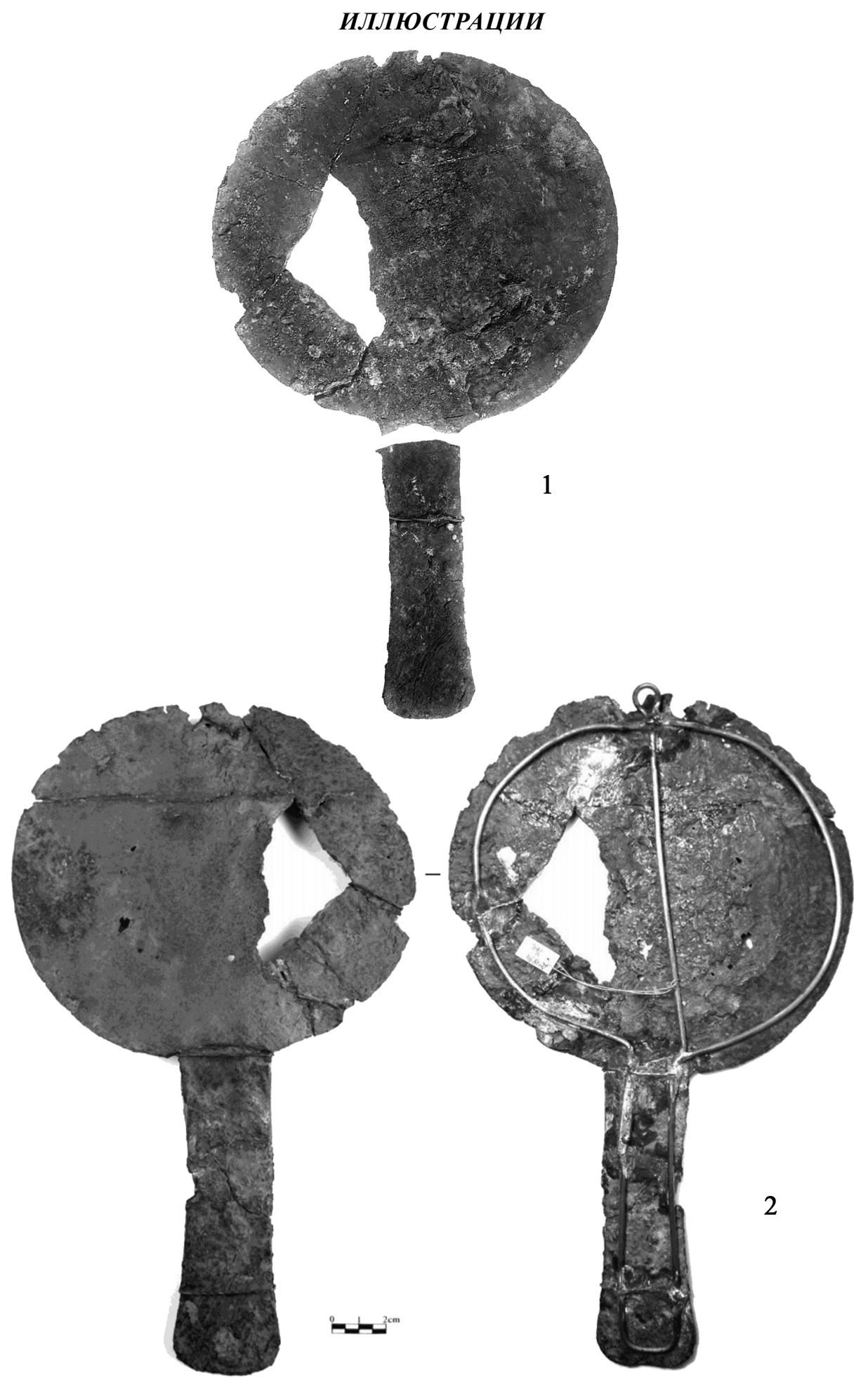

Рис. 1. Предмет с неясной функцией из кургана «Огуз»:

1 - вид до реставрации (фото Государственного Эрмитажа - ручка представлена стороной, противоположной диску) *; 2 - вид после реставрации (по: [Болтрик, Фиалко, 2011, с. 89, рис. 3])

Fig. 1. An object with an obscure function from the kurgan Oguz:

1 - view before restoration (photo of the State Hermitage Museum - the handle is represented by the side opposite to the disk)*; 2 - view after restoration (after: [Boltrik, Fialko, 2011, p. 89, fig. 3])

Примечание. * - благодарю А.Ю. Алексеева за предоставленную фотографию (I thank A.Yu. Alekseev for the photograph). 

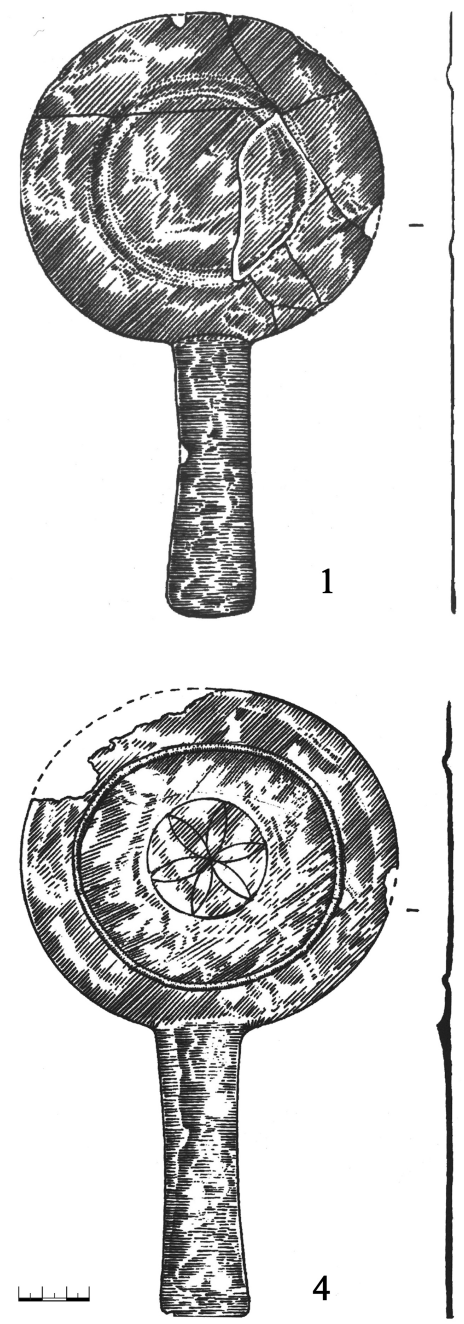
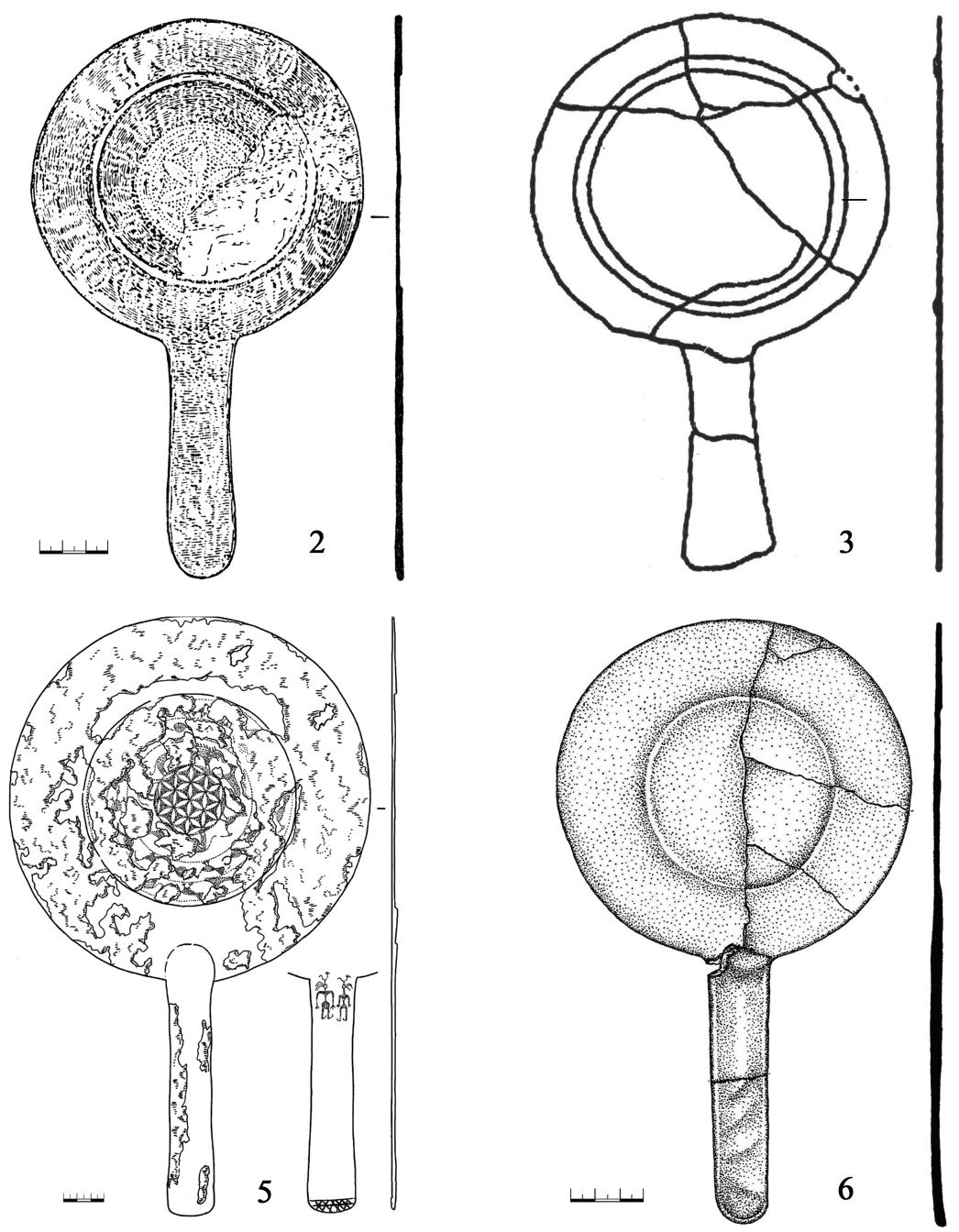

Рис. 2. Предметы с неопределенной функцией $(1,4)$ и зеркала $(2,3,5,6)$ :

1 - курган «Огуз» (по: [Кузнецова, 2010, с. 270, табл. 161] - реконструкция); 2 - Колбино-I, кург. 18, погр. 1 (по: [Гуляев, Савченко, 1999, с. 151-157, рис. 2,11]); 3 - Песочинский, кург. 8, погр. 1 (по: [Бабенко, 2005, рис. 18,5]);

4 - с. Гумарово, кург. 3, погр. 1 (по: [Кузнецова, 2010, с. 270, табл. 161]); 5 - с. Филипповка, кург. 3, погр. 1 (по: [Пшеничнюк, 2012, рис. 65]); 6 - с. Филипповка, кург. 15, погр. 1 (по: [Яблонский, 2013, № 1836])

Fig. 2. Items with an undefined function $(1,4)$ and mirrors $(2,3,5,6)$ :

1 - kurgan "Oguz" (after: [Kuznetsova, 2010, p. 270, table 161] - reconstruction); 2 - Kolbino-I, kurgan 18, burial 1 (after: [Gulyaev, Savchenko, 1999, p. 151-157, p. 2, 11]); 3 - Pesochinskiy, kurgan 8, burial 1 (after: [Babenko, 2005, fig. 18,5]);

4 - Gumarovo, kurgan 3, burial 1 (after: [Kuznetsova, 2010, p. 270, pl. 161]); 5 - Filippovka, kurgan 3, burial 1 (after: [Pshenichnyuk, 2012, fig. 65]); 6 - Filippovka, kurgan 15, burial 1 (after: [Yablonsky, 2013, no. 1836]) 
T.M. Кузнецова. К вопросу о так называемом савроматском зеркале из кургана «Огуз»

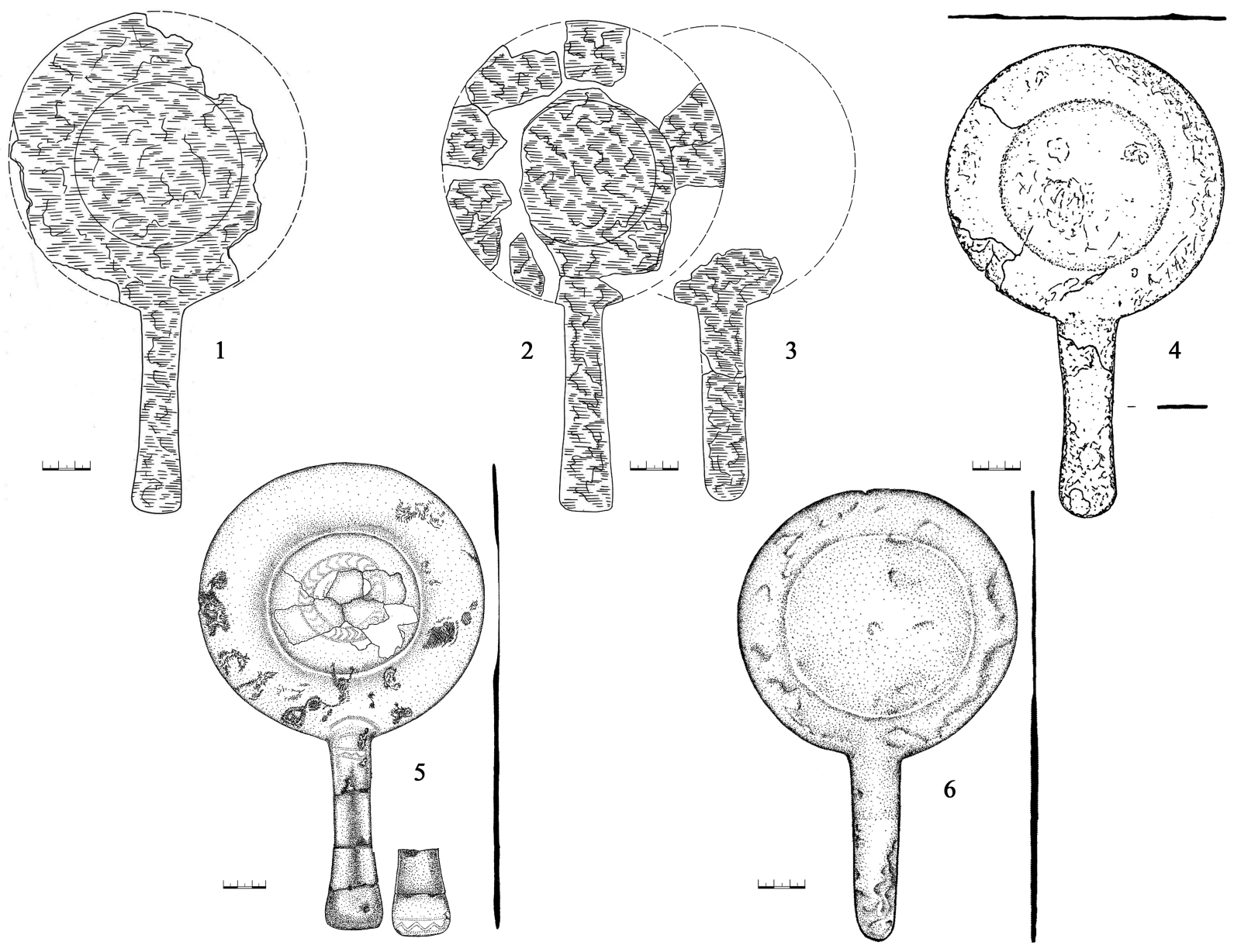

Рис. 3. Зеркала из могильника у с. Филипповка:

1, 2, 3 - кург. 7 (по: [Пшеничнюк, 2012, рис. 94, 95,1,2]);

4, 5, 6 - кург. 11, погр. 1; кург. 15, погр. 2 и 4 (по: [Яблонский, 2013, № 1496, 1840, 1969])

Fig. 3. Mirrors from the cemetery near the village of Filippovka:

1, 2, 3 - kurgan 7 (after: [Pshenichnyuk, 2012, fig. 94, 95,1,2]);

4, 5, 6 - kurgan 11, burial 1; kurgan 15, burial 2 and 4 (after: [Yablonsky, 2013, no. 1496, 1840, 1969]) 


\section{СПИСОК ЛИТЕРАТУРЫ}

Абаев В. И., 1958. Историко-этимологический словарь осетинского языка. Т. І. М. ; Л. : Изд-во АН СССР. 655 с.

Алексеев А. Ю., 1987. Хронография Скифии второй половины IV в. до н.э. // Археологический сборник Государственного Эрмитажа. Вып. 28. С. 38-51.

Андрух С. И., Тощев Г. Н., 1999. Могильник Мамай-Гора. Кн. І. Запорожье : Изд-во Запорожского университета. $231 \mathrm{c}$.

Андрух С. И., 2001. Могильник Мамай-Гора. Кн. ІІ. Запорожье : ИА НАНУ : Изд-во Запорожского университета. $282 \mathrm{c}$.

Андрух С. И., Тощев Г. Н., 2004. Могильник Мамай-Гора. Кн. ІІІ. Запорожье : Изд-во Запорожского университета. $201 \mathrm{c}$.

Андрух С. И., Тощев Г. Н., 2012. Могильник скифского времени Мамай-Гора // Peregrinationes archaeologicae in Asia et Europa. Joanni Chochorowski dedicatae. Krakyw : Wydawnictwo Profil-Archeo. C. 485-490.

Андрух С. И., Тощев Г. Н., 2018. Археологические культуры Северного Причерноморья в фокусе МамайГоры // Древние некрополи - погребально-поминальная обрядность, погребальная архитектура и планировка некрополей. Труды ИИМК РАН. Т. 47. СПб. : ИИМК РАН, Гос. Эрмитаж. С. 232-240.

Бабенко Л. И., 2005. Песочинский курганный могильник скифского времени. Харьков : ИД Райдер. 284 с.

Бессонова С. С., 1983. Религиозные представления скифов. Киев : Наукова думка. 138 с.

Бидзиля В. И., Болтрик Ю. В., Мозолевский Б. Н., Савовский И. П., 1977. Курганный могильник в урочище Носаки // Курганные могильники Рясные Могилы и Носаки. Киев : Наукова думка. С. 61-158.

Битковский О. В., Полин С. В., 1987. Скифский курган у с. Богдановка на Херсонщине (к проблеме хронологии памятников V-IV вв. до н.э.) // Скифы Северного Причерноморья. Киев : Наукова думка. С. 74-85.

Болтрик Ю. В. 2001. Поиск усыпальниц Ариапифа и его сыновей // Ольвія та античний світ : матеріали наукових читань присвячених 75-річчя утворення історико-культурного заповідника «Ольвія» НАН України. Київ : [б. и]. С. 29-31.

Болтрик Ю. В., 2016. Місце Бердянського кургану в системі поховальних пам'яток Скіфії // Старожитності раннього залізного віку. Археологія і давня історія Украини. Вип. 2 (19). Київ : ІА НАНУ. С. 27-32.

Болтрик Ю. В., 2018. Бердянский курган как ключ к пониманию устройства погребальных комплексов скифской элиты // Причерноморье в античное и раннесредневековое время : сб. науч. тр., посвящ. 70-летию проф. В.П. Копылова. Вып. 2. Ростов н/Д: ООО Лаки-Пакург. С. 309-319.

Болтрик Ю. В., Фиалко Е. Е., Чередниченко Н. Н., 1994. Бердянский курган // Российская археология. № 4. C. $140-155$.

Болтрик Ю. В., Фиалко Е. Е., 2010. Скифский курган с ранней уздой из северо-западного Приазовья // Боспорские исследования. Т. 23. С. 104-132.

Болтрик Ю. И., Фиалко Е. Е., 2011. Зеркало из кургана Огуз // Восточноевропейские древности скифской эпохи. Воронеж : Издательско-полиграфический центр «Научная книга». С. 85-97.

Бунятян Е. П., Чередниченко Н. Н., Мурзин В. Ю., 1977. Скифский могильник у с. Верхнетарасовка // Курганы юга Днепропетровщины. Киев : Наукова думка. С. 59-124.

Глебов В. П., 2019. Зеркала раннесарматской культуры Нижнего Подонья // Нижневолжский археологический вестник. Т. 18, № 2. C. 86-104. DOI: https://doi.org/10.15688/nav.jvolsu.2019.2.6

Грантовский Э. А., 1980. Проблемы изучения общественного строя скифов // Вестник древней истории. № 4. C. $128-154$.

Гуляев В. И., 2000. Там, где жили амазонки // Донская археология. № 3-4. С. 38-50.

Гуляев В. И., 2018. Скифы Северного Причерноморья в VII-IV вв. до н.э. (старые проблемы - новые решения). М. : ИА РАН. 1007 с.

Гуляев В. И., Савченко Е. И., 1999. К вопросу о роли золота в погребальном ритуале скифов // Евразийские древности. 100 лет Б.Н. Гракову: архивные материалы, публикации, статьи. М. : ИА РАН. С. 151-160.

Гуцалов С. Ю., 2009. Могильник у с. Песочин под Харьковом в контексте истории древних кочевников Южного Урала // Древности. Харьковский историко-археологический ежегодник. Вып. 8. Харьков : ООО «НТМТ». С. 69-79.

Дьяконова В. П., 1975. Погребальный обряд тувинцев как историко-этнографический источник. Л. : Наука. 163 с. 
Зуев В. Ю., Исмагилов Р. Б., 1999. Курганы у дер. Гумарово в Южном Приуралье // Археологические памятники Оренбуржья. Вып. III. Оренбург : Печатный Дом «ДИМУР». С. 103-123.

Кенин-Лопсан М. Б., 1987. Обрядовая практика и фольклор тувинского шаманства. Новосибирск : Наука. $164 \mathrm{c}$.

Кенин-Лопсан М. Б., 2009. Тувинские шаманы. М. : ООО ИПЦ «Маска». 328 с.

Королькова Е. Ф., 1997. Об одном типе бронзовых зеркал скифской эпохи // Сообщения Государственного Эрмитажа. Вып. LVII. C. 32-35.

Кузнецова Т. М., 2001а. Все зеркала, зеркала... // Материалы по археологии Волго-Донских степей. Вып. 1. Волгоград : Изд-во ВолГУ. С. 128-141.

Кузнецова Т. М., 2001б. К.Ф. Смирнов и проблема «жертвенников» // XV Уральское археологическое совещание : тез. докл. Междунар. науч. конф. (17-21 апреля 2001 г.). Оренбург : Губерния. С.132-133.

Кузнецова Т. М., 2001 в. Исторические персонажи и скифские курганы // Боспорский феномен: колонизация региона, формирование полисов, образование государства : материалы Междунар. науч. конф. Ч. 2. СПб. : Изд-во Гос. Эрмитажа. С. 141-150.

Кузнецова Т. М., 2002. Зеркала Скифии VI-III вв. до н.э. Т. 1. М. : Индрик. 352 с.

Кузнецова Т. М., 2008. Социальные индикаторы в погребальном обряде скифов (бронзовые котлы) // Проблемы современной археологии. Материалы и исследования по археологии России. № 10. М. : ИА РАН. C. 173-198.

Кузнецова Т. М., 2010. Зеркала Скифии VI-III вв. до н.э. Т. 2. М. : Таус. 426 с.

Кузнецова Т. М., 2015. Бедный Орик // Старожитності степового Причерномор'я і Криму. T. XVIII. Запоріжжя : Запорізький державний університет. С. 89-109.

Кусаева 3. К., 2016. Семиотика зеркала в фольклорно-этнографической традиции осетин // Oriental Studies. № 3. C. 63-73. DOI: https://doi.org/10.22162/2075-7794-2016-25-3-63-73.

Литвинский Б. А., 1978. Орудия труда и утварь из могильников Западной Ферганы (Археологические и этнографические материалы по истории культуры и религии Средней Азии). Могильники западной Ферганы. IV. М. : Наука. 259 с.

Могилов А. Д., 2017. Погребение рядового воина из Светловодского могильника // Історія зброї та військової справи. Ч. 1. Епоха ранньої залізної доби. № 1. Київ : Видавець Олег Філюк. С. 93-100.

Могилов А., 2019. Зеркала из Светловодского могильника // Revista Arheologicã. Serie nouã. Vol. V. Nr. 1. C. 94-102.

Мозолевский Б. Н., 1980. Скифские курганы в окрестностях г. Орджоникидзе на Днепропетровщине (раскопки 1972-1975 гг.) // Скифия и Кавказ. Киев : Наукова думка. С. 70-154.

Молок Д., 2015. Классика и истина. Статьи об античном искусстве. М. : Дефи. 296 с.

Научно-технический энциклопедический словарь, 2001. СПб. URL: https://dic.academic.ru/contents.nsf/ntes/ (дата обращения: 17.10.2019).

Полин С. В., Дараган М. Н., 2019. Зеркала в погребениях геродотовых скифов Северного Причерноморья второй половины V-IV вв. до н.э. // Античный мир и археология. Вып. 19. Саратов : Техно-Декор. C. 202-241.

Пшеничнюк А. Х., 2012. Филипповка. Некрополь кочевой знати IV в. до н.э. на Южном Урале. Уфа : ИИЯЛ УНЦРАН. $280 \mathrm{c}$.

Равич И. Г., 2006. Некоторые типы высокооловянных горячекованых зеркал сарматского времени и их технологические особенности // Краткие сообщения Института археологии. Вып. 220. С. 43-54.

Скрипкин А. С., 1990. Азиатская Сарматия. Проблемы хронологии и ее исторический аспект. Саратов : Изд-во Саратовского университета. $300 \mathrm{c}$.

Смирнов К. Ф., 1964. Савроматы. Ранняя история и культура савроматов. М. : Наука. 380 с.

Современный толковый словарь, 1998. M. URL: https://dic.academic.ru/contents.nsf/enc3p/ (дата обращения: 17.10.2019).

Тайлор Э. Б., 1989. Первобытная культура. М. : Политиздат. 573 с.

Тереножкин А. И., Ильинская В. А., Черненко Е. В., Мозолевский Б. Н., 1973. Скифские курганы Никопольщины // Скифские древности. Киев : Наукова думка. С. 113-186.

Фасмер М., 1986. Этимологический словарь русского языка. Т. ІІ. М. : Прогресс. 671 с. 
Фиалко Е. Е., 2011. Зеркала в обрядах скифов // Боспорские исследования. Вып. XXV. С. 79-94.

Фрезер Д. Д., 1980. Золотая ветвь. Исследование магии и религии. М. : Политиздат. 832 с.

Хедаят Садек, 1958. Нейрангистан : пер. с персид., предисл. и коммент. Н.А. Кислякова // Переднеазиатский этнографический сборник. І. Труды института этнографии им. Н.Н. Миклухо-Маклая. Новая серия. T. XXXIX. М. : Наука. С. 259-336.

Чередниченко Н. Н., Фиалко Е. Е., 1988. Погребение жрицы из Бердянского кургана // Советская археология. №2. С. 149-166.

Яблонский Л. Т., 2013. Золото сарматских вождей. Элитный некрополь Филипповка 1 (по материалам раскопок 2004-2009 гг.). Каталог коллекции. Книга 1. М. : ИА РАН. 232 с.

Яблонский Л. Т., 2015. Новые необыкновенные находки из кургана 1 могильника Филипповка-1 // Археология, этнография и антропология Евразии. Т. 43, № 2. С. 97-108.

Albenda P., 1985. Mirrors in the Ancient Near East // Source: Notes in the History of Art. Vol. 4. Nos. 2/3. P. $2-9$.

Schmidt E. F., 1937. Excavations at Tepe Hissar, Damghan. Philadelphia : The university museum. 478 p.

Woolley L., 1934a. Ur Excavations. The Royal Cemetery. Vol. II. Text. Oxford : Joint Expedition of the British Museum and of The Museum of the University of Pennsylvania to Mesopotamia. $604 \mathrm{p}$.

Woolley L., 1934b. Ur Excavations. The Royal Cemetery. Vol. II. Plates. Oxford : Joint Expedition of the British Museum and of The Museum of the University of Pennsylvania to Mesopotamia. $274 \mathrm{pl}$.

\section{REFERENCES}

Abayev V.I., 1958. Istoriko-etimologicheskiy slovar osetinskogo yazyka [Historical and Etymological Dictionary of the Ossetian Language], vol. I. Moscow, Leninrad, AS USSR. 655 p.

Alekseyev A.Yu., 1987. Khronografiya Skifii vtoroy poloviny IV v. do n.e. [Scythian Chronography of the Second Half of the Fourth Century B. C.]. Arkheologicheskiy sbornik Gosudarstvennogo Ermitazha [Archaeological Papers of the State Hermitage Museum], iss. 28, pp. 38-51.

Andrukh S.I., Toshchev G.N., 1999. Mogilnik Mamay-Gora [Mamay-Gora Necropolis], book I. Zaporozhye, Zaporozhye State University. $231 \mathrm{p}$.

Andrukh S.I., 2001. Mogilnik Mamay-Gora [Mamay-Gora Cemetery]. Book II. Zaporozhye, IA NASU, Zaporozhye State University. 282 p.

Andrukh S.I., Toshchev G.N., 2004. Mogilnik Mamay-Gora [Mamay-Gora Necropolis], book III. Zaporozhye, Zaporozhye State University. $201 \mathrm{p}$.

Andrukh S.I., Toshchev G.N., 2012. Mogilnik skifskogo vremeni Mamay-Gora [Necropolis of the Scythian Time Mamai-Gora]. Peregrinationes archaeologicae in Asia et Europa. Joanni Chochorowski dedicatae. Krakyw, Wydawnictwo Profil-Archeo, pp. 485-490.

Andrukh S.I., Toshchev G.N., 2018. Arkheologicheskiye kultury Severnogo Prichernomoria v fokuse Mamay-Gory [Archaeological Cultures of Northern Black Sea Coast in Focus of Mamai-Gora]. Drevniye nekropolipogrebalno-pominalnaya obryadnost', pogrebalnaya arkhitektura i planirovka nekropoley. Trudy IIMK $R A N$ [Ancient Necropolises - Funeral and Memorial Ritualism, Architecture and Planning of Necropolises. Proceedings of the Institute for the History of Material Culture RAS], vol. 47. Saint Petersburg, Institute for the History of Material Culture RAS, State Hermitage Museum, pp. 232-240.

Babenko L.I., 2005. Pesochinskiy kurgannyy mogilnik skifskogo vremeni [Pesochinsky Kurgan Cemetery of Scythian Time]. Kharkov, ID Rayder Publ. 284 p.

Bessonova S.S., 1983. Religioznyye predstavleniya skifov [Religious Representations of the Scythians]. Kiev, Naukova dumka Publ. $138 \mathrm{p}$.

Bidzilya V.I., Boltrik Yu.V., Mozolevskiy B.N., Savovskiy I.P., 1977. Kurgannyy mogilnik v urochishche Nosaki [Kurgan Cemetery in the Area Nosaki]. Kurgannyye mogilniki Ryasnyye Mogily i Nosaki [Kurgan Cemetery Raznye Mogily and Nosaki]. Kiev, Naukova dumka Publ., pp. 61-158.

Bitkovskiy O.V., Polin S.V., 1987. Skifskiy kurgan u s. Bogdanovka na Khersonshchine (k probleme khronologii pamyatnikov V-IV vv. do n.e.) [Scythian Kurgan Near the Village Bogdanovka in the Kherson Region (To the Problem of the Chronology of Monuments of the $5^{\text {th }}-4^{\text {th }}$ Centuries BC)]. Skify Severnogo Prichernomoria [Scythians of the Northern Pontic Region]. Kiev, Naukova dumka Publ., pp. 74-85. 
Boltrik Yu.V., 2001. Poisk usypalnits Ariapifa i ego synovey [Search for the Tombs of Ariapith and his Sons]. Olviya ta antichniy svit: materiali naukovikh chitan prisvyachenikh 75-richchya utvorennya istoriko-kulturnogo zapovidnika «Olviya» NAN Ukraïni [Olbia and the Ancient World. Materials of Scientific Readings Dedicated to the $75^{\text {th }}$ Anniversary of the Creation of the Olbia Historical and Cultural Reserve of the NAS of Ukraine]. Kiev, pp. 29-31.

Boltrik Yu.V., 2016. Mistse Berdyanskogo kurganu v sistemi pokho-valnikh pam'yatok Skifiï [The Place of Berdiansk Kurgan in the System of Burial Monuments of Scythia]. Starozhitnosti rannogo zaliznogo viku. Arkheologiya i davnya istoriya Ukrainu [Antiquities of the Early Iron Age. Archeology and Ancient History of Ukraine], iss. 2 (19). Kiev, IA NASU, pp. 27-32.

Boltrik Yu.V., 2018. Berdyanskiy kurgan kak klyuch k ponimaniyu ustroystva pogrebalnykh kompleksov skifskoy elity [Berdyansk Kurgan as a Key to Understanding the Structure of Funeral Complexes of Skythian Elite]. Prichernomorye v antichnoye i rannesrednevekovoye vremya: sb. nauch. tr., posvyashch. 70letiyu prof. V.P. Kopylova [The Black Sea Region in Antiquity and Early Middleages. Papers Presented to V.P. Kopylov on the Occasion of his $70^{\text {th }}$ Birthday], iss. 2. Rostov-on-Don, OOO Laki-Pakurg Publ., pp. 309-319.

Boltrik Yu.V., Fialko E.E., Cherednichenko N.N., 1994. Berdyanskiy kurgan [Berdyansk Kurgan]. Rossiyskaya arkheologiya [Russian Archaeology], no. 4, pp. 140-155.

Boltrik Yu.V., Fialko E.E., 2010. Skifskiy kurgan s ranney uzdoy iz severo-zapadnogo Priazovia [Scythian Burial Mound with an Early Bridle from North-Western Azov Sea Area]. Bosporskiye issledovaniya [Bosporos Studies], vol. 23, pp. 104-132.

Boltrik Yu.I., Fialko E.E., 2011. Zerkalo iz kurgana Oguz [Mirror from the Oguz Kurgan]. Vostochnoyevropeyskiye drevnosti skifskoy epokhi [East European Antiquities of the Scythian Era]. Voronezh, Publishing and Printing Center "Nauchnaya kniga", pp. 85-97.

Bunyatyan E.P., Cherednichenko N.N., Murzin V.Yu., 1977. Skifskiy mogilnik u s. Verkhnetarasovka [Scythian Kurgan Cemeteries Near the Village Verkhnetarasovka]. Kurgany yuga Dnepropetrovshchiny [Kurgans of the South of Dnepropetrovsk]. Kiev, Naukova dumka Publ., pp. 59-124.

Glebov V.P., 2019. Zerkala rannesarmatskoy kultury Nizhnego Podonia [Mirrors of the Early Sarmatian Culture of the Lower Don Region]. Nizhnevolzhskiy arkheologicheskiy vestnik [The Lower Volga Archeological Bulletin], vol. 18, no. 2, pp. 86-104. DOI: https://doi.org/10.15688/nav.jvolsu.2019.2.6.

Grantovskiy E.A., 1980. Problemy izucheniya obshchestvennogo stroya skifov [Problems of Studying the Social System of Scythians]. Vestnik drevney istorii [Journal of Ancient History], no. 4. pp. 128-154.

Gulyayev V.I., 2000. Tam, gde zhili amazonki [Where the Amazons Lived]. Donskaya arkheologiya [Don Archeology], no. 3-4, pp. 38-50.

Gulyayev V.I., 2018. Skify Severnogo Prichernomoria v VII-IV vv. do n.e. (staryye problemy-novyye resheniya) [Scythians of the North Pontic Region in the $7^{\text {th }}-4^{\text {th }}$ Centuries BC (Old Problems - New Solutions)]. Moscow, IA RAS. $1007 \mathrm{p}$.

Gulyayev V.I., Savchenko E.I., 1999. K voprosu o roli zolota v pogrebalnom rituale skifov [About the Role of Gold in Scythian Burial Rites]. Evraziyskiye drevnosti. 100 let B.N. Grakovu: arkhivnyye materialy, publikatsii. stati [Eurasian Antiquities. The Centenary of Boris N. Grakov: The Archival Materials, Publications, Papers]. Moscow, IA RAS, pp. 151-160.

Gutsalov S.Yu., 2009. Mogilnik u s. Pesochin pod Kharkovom v kontekste istorii drevnikh kochevnikov Yuzhnogo Urala [The Groves Near the Village Pesochin Under Kharkov in the Context of the South Ural Ancient Nomads History]. Drevnosti. Kharkovskiy istoriko-arkheologicheskiy ezhegodnik [Antiquities. Kharkov Historical and Archaeological Yearbook], iss. 8. Kharkov, OOO "NTMT" Publ., pp. 69-79.

Diakonova V.P., 1975. Pogrebalnyy obryad tuvintsev kak istoriko-etnograficheskiy istochnik [The Funeral Rite of Tuvans as a Historical and Ethnographic Source]. Leningrad, Nauka Publ. 163 p.

Zuyev V.Yu., Ismagilov R.B., 1999. Kurgany u der. Gumarovo v Yuzhnom Priuralye [Barrows near the Village Gumarovo in the South Urals]. Arkheologicheskiye pamyatniki Orenburzhia [Archaeological Monuments of the Orenburg Region], iss. III. Orenburg, Printing House "DIMUR", pp. 103-123.

Kenin-Lopsan M.B., 1987. Obryadovaya praktika ifolklor tuvinskogo shamanstva [Ritual Practice and Folklore of Tuvan Shamanism]. Novosibirsk, Nauka Publ. 164 p.

Kenin-Lopsan M.B., 2009. Tuvinskiye shamany [Tuvan Shamans]. Moscow, Maska Publ., 328 p. 
Korolkova E.F., 1997. Ob odnom tipe bronzovykh zerkal skifskoy epokhi [About one Type of Bronze Mirrors of the Scythian Era]. Soobshcheniya Gosudarstvennogo Ermitazha [Reports of the State Hermitage Museum], iss. LVII, pp. 32-35.

Kuznetsova T.M., 2001a. Vse zerkala, zerkala... [Those Mirrors, Mirrors...]. Materialy po arkheologii VolgoDonskikh stepey [Materials on the Archeology of the Volga-Don Steppes], iss. 1. Volgograd, Volgograd State University, pp. 128-141.

Kuznetsova T.M., 2001b. K.F. Smirnov i problema «zhertvennikov» [K.F. Smirnov and the Problem of “Altars”]. XV Uralskoye arkheologicheskoye soveshchaniye: tez. dokl. Mezhdunar. nauch. konf. (17-21 aprelya 2001 g.) [XV Ural Archaeological Meeting: Theses of the Reports International Scientific Conference (April 1721, 2001)]. Orenburg, Guberniya Publ., pp. 132-133.

Kuznetsova T.M., 2001v. Istoricheskiye personazhi i skifskiye kurgany [Historical Characters and Scythian Barrows]. Bosporskiy fenomen: kolonizatsiya regiona, formirovaniye polisov, obrazovaniye gosudarstva: materialy Mezhdunar. nauch. konf. [Bosporus Phenomenon: Colonization of the Region, Formation of Poleis, Formation of the State. Materials of the International Scientific Conference], part 2. Saint Petersburg, State Hermitage Museum, pp. 141-150.

Kuznetsova T.M., 2002. Zerkala Skifii VI-III vv. do n.e. [Mirrors of Scythia of VI-III Centuries BC], vol. 1. Moscow, Indrik Publ. $352 \mathrm{p}$.

Kuznetsova T.M., 2008. Sotsialnyye indikatory v pogrebalnom obryade skifov (bronzovyye kotly) [Social Indicators in the Funeral Rite of the Scythians (Bronze Cauldrons)]. Problemy sovremennoy arkheologii. Materialy $i$ issledovaniya po arkheologii Rossii [Problems of Modern Archeology. Materials and Research on Archeology of Russia], no. 10. Moscow, IA RAS, pp. 173-198.

Kuznetsova T.M., 2010. Zerkala Skifii VI-III vv. do n.e. [Mirrors of Scythia of VI-III Centuries BC], vol. 2. Moscow, Taus Publ. 426 p.

Kuznetsova T.M., 2015. Bednyy Orik [Poor Orik]. Starozhytnosti stepovoho Prychernomor 'ia i Krymu [Antiquities of the Steppe of the Black Sea and Crimea], vol. XVIII. Zaporozhye, Zaporozhye State University, pp. 89-109.

Kusayeva Z.K., 2016. Semiotika zerkala v folklorno-etnograficheskoy traditsii osetin [Semiotics of Mirror in Folklore and Ethnographic Traditions of Ossetians]. Oriental Studies, no. 3, pp. 63-73. DOI: https://doi.org/10.22162/ 2075-7794-2016-25-3-63-73.

Litvinskiy B.A., 1978. Orudiya truda $i$ utvar iz mogilnikov Zapadnoy Fergany (Arkheologicheskiye $i$ etnograficheskiye materialy po istorii kultury i religii Sredney Azii). Mogilniki zapadnoy Fergany [Tools and Utensils from the Cemeteries of Western Ferghana (Archaeological and Ethnographic Materials on the History of Culture and Religion of Central Asia). Cemeteries of Western Ferghana], iss. 4. Moscow, Nauka Publ. 259 p.

Mogilov A.D., 2017. Pogrebeniye ryadovogo voina iz Svetlovodskogo mogilnika [The Burial of Ordinary Warrior from Svitlovodsk Cemetery]. Istoriia zbroi ta viiskovoi spravy. Chast' 1. Epokha rannoi zaliznoi dobi [History of Weapons and Warfare. Part1. Early Iron Age], no. 1. Kiev, Vydavets Oleg Filyuk Publ., pp. 93-100.

Mogilov A., 2019. Zerkala iz Svetlovodskogo mogilnika [Mirrors from the Svitlovodsk Cemetery]. Revista Arheologicã. Serie nouã, vol. V, no. 1, pp. 94-102.

Mozolevskiy B.N., 1980. Skifskiye kurgany v okrestnostyakh g. Ordzhonikidze na Dnepropetrovshchine (raskopki 1972-1975 gg.) [Scythian Kurgans in the Vicinity of the City of Ordzhonikidze in the Dnepropetrovsk Region (Excavations of 1972-1975)]. Skifiya i Kavkaz [Scythia and the Caucasus]. Kiev, Naukova dumka Publ., pp. $70-154$.

Molok D., 2015. Klassika i istina. Stati ob antichnom iskusstve [Classic and True. Articles about Ancient Art]. Moscow, Defi Publ. 296 p.

Nauchno-tekhnicheskiy entsiklopedicheskiy slovar, 2001 [Scientific and Technical Encyclopedic Dictionary]. Saint Petersburg. URL: https://dic.academic.ru/contents.nsf/ntes/ (accessed 17.10.2019).

Polin S.V., Daragan M.N., 2019. Zerkala v pogrebeniyakh gerodotovykh skifov Severnogo Prichernomoria vtoroy poloviny V-IV vv. do n.e. [Mirrors in the Burials of the Scythians of Herodot of the Northern Black Sea Coast of the Second Half of the $\mathrm{V}^{\text {th }}-\mathrm{IV}^{\text {th }}$ Centuries BC]. Antichnyy mir $i$ arkheologiya [Ancient World and Archaeology], iss. 19. Saratov, Tekhno-Dekor Publ., pp. 202-241.

Pshenichnyuk A.Kh., 2012. Filippovka. Nekropol kochevoy znati IV v. do n.e. na Yuzhnom Urale [Filippovka. Necropolis of Nomadic Nobility IV Century BC in the Southern Urals]. Ufa, IHLL USC RAS. 280 p. 
Ravich I.G., 2006. Nekotoryye tipy vysokoolovyannykh goryachekovanykh zerkal sarmatskogo vremeni i ikh tekhnologicheskiye osobennosti [Some Types of High Tin Hot-Forged Mirrors of Sarmatian Time and Their Technological Features]. Kratkiye soobshcheniya Instituta arkheologii [Brief Reports of the Institute of Archeology], iss. 220, pp. 43-54.

Skripkin A.S., 1990. Aziatskaya Sarmatiya. Problemy khronologii i eye istoricheskiy aspect [Asian Sarmatia. Problems of Chronology and Its Historical Aspect]. Saratov, Saratov State University. 300 p.

Smirnov K. F., 1964. Savromaty. Rannyaya istoriya i kultura savromatov [Sauromats. Early Sarmatian History and Culture]. Moscow, Nauka Publ. 380 p.

Sovremennyy tolkovyy slovar', 1998 [Modern Explanatory Dictionary]. Moscow. URL: https://dic.academic.ru/ contents.nsf/enc3p/ (accessed 17.10.2019).

Taylor E.B., 1989. Pervobytnaya kultura [Primitive Culture]. Moscow, Politizdat Publ. 573 p.

Terenozhkin A.I., Ilinskaya V.A., Chernenko E.V., Mozolevskiy B.N., 1973. Skifskiye kurgany Nikopolshchiny [Scythian Kurgans of the Nikopol Region]. Skifskiye drevnosti [Scythian Antiquities]. Kiev, Naukova dumka Publ., pp. 113-186.

Fasmer M., 1986. Etimologicheskiy slovar russkogo yazyka [Etymological Dictionary of the Russian Language], vol. II. Moscow, Progress Publ. 671 p.

Fialko E.E., 2011. Zerkala v obryadakh skifov [Mirrors in the Rites of the Scythians]. Bosporskiye issledovaniya [Bosporos Studies], iss. XXV, pp. 79-94.

Frazer J.G., 1980. Zolotaya vetv. Issledovaniye magii i religii [The Golden Bough. A Study in Magic and Religion]. Moscow, Politizdat Publ. 832 p.

Khedayat Sadek, 1958. Neyrangistan [Neyrangistan]. Peredneaziatskiy etnograficheskiy sbornik. I. Trudy instituta etnografii im. N.N. Miklukho-Maklaya. Novaya seriya [East Asian Ethnographic Collection. I. Proceedings of N.N. Miklouho-Maclay Institute of Ethnography. New Series], vol. XXXIX. Moscow, Nauka Publ., pp. 259-336.

Cherednichenko N.N., Fialko E.E., 1988. Pogrebeniye zhritsy iz Berdyanskogo kurgana [A Priestess' Burial in the Berdyansk Mound]. Sovetskaya arkheologiya [Soviet Archaeology], no. 2, pp. 149-166.

Yablonskiy L.T., 2013. Zoloto sarmatskikh vozhdey. Elitnyy nekropol' Filippovka 1 (po materialam raskopok 2004-2009 gg.). Katalog kollektsii [Gold of Sarmatian Leaders. Elite Necropolis Filippovka 1 (Based on Excavations from 2004-2009). Collection Catalog]. Book 1. Moscow, IA RAS. 232 p.

Yablonskiy L.T., 2015. Novyye neobyknovennyye nakhodki iz kurgana 1 mogilnika Filippovka-1 [New Unusual Finding at Fillipovka-1 Burial Mound 1, Southern Urals]. Arkheologiya, etnografiya i antropologiya Evrazii [Archaeology, Ethnology \& Anthropology of Eurasia], vol. 43, no. 2, pp. 97-108.

Albenda P., 1985. Mirrors in the Ancient Near East. Source: Notes in the History of Art, vol. 4, nos. 2/3, pp. 2-9.

Schmidt E. F., 1937. Excavations at Tepe Hissar, Damghan. Philadelphia, The university museum. 478 p.

Woolley L., 1934a. Ur Excavations. The Royal Cemetery. Vol. II. Text. Oxford, Joint Expedition of the British Museum and of The Museum of the University of Pennsylvania to Mesopotamia. 604 p.

Woolley L., 1934 b. Ur Excavations. The Royal Cemetery. Vol. II. Plates. Oxford, Joint Expedition of the British Museum and of The Museum of the University of Pennsylvania to Mesopotamia. $274 \mathrm{pl}$.

\section{Information About the Author}

Tatiana M. Kuznetsova, Candidate of Historical Sciences, Senior Researcher, Institute of Archaeology of the Russian Academy of Sciences, Dm. Ulyanova St., 19, 117036 Moscow, Russian Federation, mamulya-kuznecova@yandex.ru,https://orcid.org/0000-0001-7926-2721

\section{Информация об авторе}

Татьяна Михайловна Кузнецова, кандидат исторических наук, старший научный сотрудник, Институт археологии РАН, ул. Дм. Ульянова, 19, 117036 г. Москва, Российская Федерация, mamulya-kuznecova@yandex.ru, https://orcid.org/0000-0001-7926-2721 